\title{
Geo-strategic importance of Nepal
}

\section{Dharma Bahadur Baniya}

If you know a country's geography, you can understand and predict its foreign policy.

Napoleon Bonaparte

\begin{abstract}
The destiny of a country, to a great extent, depends upon its geo-strategic position in the world. Nepal's unique geo-strategic position has contributed to expand its roles and enhance its strategic significance in the regional as well as the global affairs. Our neighbors are taking interest in Nepal mainly because of its connectivity potential, natural resources and their security concerns. By realizing our geo-strategic importance, immediate neighbors and some established powers are trying to expand their influences in various forms, over Nepal. With this background, this article forwards relevant recommendations to exploit maximum benefits by analyzing the importance of geostrategic position of Nepal.
\end{abstract}

Keywords: balance, connectivity, foreign policy, geo-strategic, linked state, security

\section{Introduction}

Geo-strategy, a subfield of geopolitics (Couto, 1988) demonstrates the importance of a country or a region by virtue of its geographical location. It is concerned with matching means to ends - in this case, a country's resources with its geopolitical objectives (Garafano, July 2004). Geographical factors of a state bring both, some risks to evade and some strength as well as opportunities to avail. When a state learns to exploit its geography to the best of its strategic interests, then it will be able to ensure enduring survivability. Geo-strategy can direct how foreign policy of a state is shaped by its geography. Strategy is interconnected with geography as geography is with nationhood. Hence, geography is the mother of strategy (Gray \& Sloan, 1999, p. 3). Geography is the most fundamental conditioning factor in the foreign policy of states because it is the most permanent (Spykeman, 1944, p. 7).

As proclaimed by King Prithvi Narayan Shah, Nepal is a "Yam between two Boulders". Nepal is well known for its geostrategic position and natural resources in the world. Our immediate neighbors as well as established powers have taken keen interest in expanding their sphere of influence in Nepal. Geo-strategic significance has always been an important factor in shaping foreign policy, security and development of Nepal.

\section{Geographical description}

Federal Democratic Republic of Nepal is situated in South Asia between two oversized, economically and militarily mighty neighbors, China and India. It has an area of 1, 47, 181sq $\mathrm{km}$ (fourty-fifth biggest country in the world) with 29 million populations (Sigdel, 03 Oct 
2018). With average length and width of 885 $\mathrm{km}$ and $193 \mathrm{~km}$, it is 65 times and 22 times smaller than China and India, respectively (Kumar, 2017, pp. 30-31). Nepal shares $1414 \mathrm{~km}$ border (15 districts) with China's Tibet autonomous region (TAR) from north and $1880 \mathrm{~km}$ border (23 districts) with India (Uttarakhand, Uttar Pradesh \& Bihar, West Bengal and Sikkim) from West, South and East. There are few land connectivity passes towards China due to the high altitude terrain configuration, whereas southern border enjoys with a number of all seasoned transportation infrastructures. Nepal's geostrategic orientation is approximately northwest to the south-east with a rectangular shape having limited strategic depth with abrupt altitude variation.

\section{Geo-strategic importance of Nepal}

Nepal, with its strong geo-strategic position between two Asian giants, constitutes an integral part in their strategic interests in South Asian Region (SAR). The analysis of the important geo-strategic factors is presented in subsequent paragraphs.

\section{Geopolitical competition}

In bilateral political relations, regional affairs and international forums... China treats Nepal as its closest neighbor and best friend (Dahal, 2018, p. 50). Enduring cordial SinoNepal relation has provided an opportunity to China to expand its multi-faceted engagements in Nepal; those were earlier enjoyed by southern neighbor. Nepal with its limited strategic depth also provides shortest China - SAR gateway, particularly to a large Indian market of Uttar Pradesh (UP) and Bihar. President Xi Jinping's commitment during his recent visit to fully support Nepal becoming a "land-linked" also demonstrates that China is willing to play a dynamic role in Nepal.

Indian hegemonic behavior along with the number of problemsin Indo-Nepal relations such as unequal treaties (1950 India-Nepal Treaty of Peace and Friendship), border encroachments (Limpiadhura, Kalapani, Lipulek, Susta...) and other controversial issues (political insecurity in Terai /Madesh, Trade and Commerce, water resources Koshi, Gandaki, Mahakali...) has created an opportunity in the rise of Chinese influence over Nepal (Kavita, 2016,p. 12). This situation could undermine both India's influence and its strategic equations with Nepal and the SAR. This kind of competition has made Nepal as an indispensable component of their strategic interests, and thus, enhancing our values not only within SAR but also in the Indo-Pacific region.

Nepal is also immensely important for the strategic interests of the United States of America (US) and wants to keep on its radar by helping in its socio-economic development, democracy and security. The US security interpretation is highlighted as a result of Chinese investment to build deep sea ports along the rim of Indian Ocean from Gwadar (Pakistan, China-Pakistan Economic Corridor-CPEC) through Kyaukpyu (Myanmar), Chittagong (Bangladesh) to Hambantota (Sri Lanka), also referred as 'String of Pearls'. The US anticipates the 'String of Pearls' as a strategic alliance of China for the containment of the US along Indo-Pacific region. Therefore, the US has offered a dominant role to India in IndoPacific Strategy (IPS) and 'Quad' consisting of Australia, India, Japan and the US. Further, India's Act East Policy and Modi's visualization of 'security and growth for the entire region (SAGAR)' also reveals a strong 
Indo-US strategic alignment (Bhardwaj, 23 Jan 2020). In this emerging strategic environment, Nepal's strategic significance has been further enhanced by the US-led West's efforts to include Nepal, so that it could be used as a lever in the IPS targeting Chinese influence including belt and road initiative (BRI).

\section{Security concerns}

The primary concern of China and India in Nepal is that any security problems in Nepal would have spillover effects to their security. China understands any instability in Nepal might strengthen anti-China elements and seeks supports in controlling Tibetan exiles in Nepal (Rajagopalan, 17 Oct 2019). China perceives that cordial and friendly SinoNepal relations could support them resolve genuine problems in the future in TAR, including the Indo-US's potential threat in the region. Nepal's geo-strategic position comes in the front in these equations where China respects Nepal as a reliable neighbor. Next to Pakistan, Nepal receives the second priority in China's strategic calculation in the region.

Nepal has an immense strategic relevance to the Indian security as well. India's anxiety is that any overwhelming foreign interests have the possibility of Nepalese territory to be used in anti-India activities, including their security and strategic interests (Dorji, 17 Oct 2019). India also visualizes that Chinese influence in Nepal and deep Sino-Pak relations would threaten India and provide greater concealment to Pakistani terrors aiming India through weakly regulated Indo-Nepal border. Further, Nepal shares a $1414 \mathrm{~km}$ long border with TAR, where Nepal is virtually helping India not to deploy substantial border security forces. Perhaps this is the only section in the
Himalayas, where there are no / negligible security threats to India from Nepal.

China's main concern in Nepal is primarily the US not India. China suspects that the US and its allies are trying to use Nepal in their larger strategy of encircling China. This has led China to be more active in Nepal in recent years.

\section{Balance of power considerations}

Nepal always supported China's admission to the United Nations, other international agencies and "One China policy". China perceives that Nepal provides an opportunity of balancing India within the SAR itself. India's unpredictable relations with Nepal make an attractive partner for China. Being the gateway to China's problematic SAR, a viable bridge connecting TAR and a BRI partner, Nepal is strategically important in the Chinese South Asian policy.

Nepal wants to reduce over dependency on India by building connectivity linkages with China. Acloser Sino-Nepal relationship compels India to be more careful to Nepali concerns, asserts India to be more attentive in alienating Nepal, pays more attention to Nepali connectivity requirements and hydroelectric exploration. China's role in Nepal has had positive results, forcing India to deliver more, as the recent completion of an oil pipeline ahead of schedule.India, to its credit, is realizing that it can no longer treat Nepal and other states like colonial dependencies (Stone, 2019).

India perceives a growing Chinese influence in SAR, particularly in Nepal, as a part of Chinese larger strategy to encircle India. India wants to maintain its influence in Nepal while China endeavors to increase its influence and space to make stronger foothold. 


\section{North-South connectivity}

Nepal's participation in the BRI on May 12, 2017, includes connectivity with the overarching framework of trans-Himalayan Multi-Dimensional Connectivity Network of ideas, trade, energy, people, finance and the whole spectrum of connectivity (Singh, 23 April 2019). The strategic agreement will give rights to Nepal's access to the Chinese seaports. If implemented cautiously, the BRI can potentially project Nepal to a strategic force in the region.

The Qinghai-Tibet railways extension from Lhasa-Sighatse $(253 \mathrm{Km})$, the closest Tibetan city to Nepal, has been completed by 2014. China has agreed to extend 72 $\mathrm{km}$ railway from Sighatse-Kathmandu and then to Pokhara and Lumbini. The proposed Sigatse-Kerung-Kathmandu railway as a part of BRI is considered a game changer in Nepal's aspiration for economic prosperity as it will end India's monopoly in Nepal's sea transportations.

To prevent Nepal's inclination towards China, India also has announced to construct Raxual-Kathmandu and east-west railway (Kakarvitta, Jhapa - Gaddachauki, Kanchanpur, $924.80 \mathrm{~km}$ ) lines parallel to the east-west highway (Shah, 18 Dec 2019). With $72 \mathrm{~km}$ between Sighatse-Kathmandu and $200 \mathrm{~km}$ between Kathmandu - Birgunj, the road distance between the northern to southern borders is not more than $300 \mathrm{~km}$. Hence, Nepal can comfortably link two giant economies through its land territory. At present, Sino-Indian trade is taking place by over $5000 \mathrm{~km}$ of rails / roads plus sea transportations. This connectivity through Nepal would create wonders to all the countries involved.
Over the past decades, the volume of SinoIndian bilateral trade has increased by many folds. But, there are no all seasoned trade routes to connect their geography (Sinha, 2005, pp. 27 -30). The Nathu La Pass (Sikkim) located at an altitude of 4400 meter closed after the 1962 Sino-Indian war and reopened in 2006, is the only operational land route between them. It is mostly snowbound, risky, far from major industrial bases and not operational in all seasons. India also have unsettled border problem in the north-east (Arunachal Pradesh) and north-west frontiers (Ladakh). Now, China is concentrating its development activities in TAR and Xinjiang and India on northeast and the north-west frontiers, which are relatively backward. Having unfeasible Nathu La Pass, unsettled territorial disputes and dependency on expensive air / maritime transportations, Nepal corridor provides tremendous connectivity opportunity of trade between these new growth centers (Mitra \& Roy, 2005, pp. 286-303) of China and India.

\section{Bridging South Asia and Central Asia}

China is making big investment on its western region as well as into the Central Asian Republics (CAR). Its plan of connecting its trouble ridden Xinjiang to Lhasa by High speed train within 2020 opens up the opportunity of linking resources laden CAR with resources deficit SAR through Nepal. Nepal corridor will open up a new landscape for inter-regional economic cooperation.

China from its western border, India via Iran Afghanistan and the US via Pak-Afghan land corridor, are having geopolitical competition in SAR. Since China and India are the two rising trade partners, Nepal's connectivity corridor could provide transit link to fulfill 
India's ambition in Central Asian investment, trade, energy, security and geopolitics (Nepal, 2006, p. 22).

\section{Hydroelectric potential: Nepal's} hydroelectric potential is estimated to be as high as $83,000 \mathrm{MW}$, out of which $42,000 \mathrm{MW}$ is considered technically feasible. Nepal's hydroelectricity can support the Sino-Indian industrialization and economic growth. Recent discussions reveal that India and Bangladesh plan to buy 15600 MW by 2034 and 9000 MW by 2040 respectively from Nepal. Sri Lanka also has shown interest in our hydroelectricity via India. China would need energy for the development of TAR and in the implementation of BRI in Nepal. If our diplomacy takes proper directives, possibilities are there of integrating our hydroelectricity not only within SAARC and BBIN countries, but also to TAR, BIMSTEC and ASEAN countries with land connectivity.

Tourism: Nepal has a tremendous potential to become a top destination for tourists as the nation is famous for its snowcapped mountains with eight of 10 highest mountains of the world including Mt. Everest, abundant flora and fauna, exciting trekking routes and rich cultural and religious diversity. Nepal is located between the most populous countries China and India 1.42 and 1.35 billion respectively, totaling 2.8 billion, together comprises of 36 percent of world population. Even if just 0.50 percent ( 14 million) of them visit Nepal every year, it will give wonders to Nepalese economy. This has been possible only because of our unique geo-strategic position.

Experimental place for global climate change: There is a common agreement that climate change is impacting Nepal disproportionately compared to its size and its negligible contribution of the greenhouse gases. Our mountains are becoming more vulnerable due to increased carbon emissionand extreme altitude variation over small distances. Nepal's central location in the Himalayas with altitude variation from $52-8848$ meter within the average width of $193 \mathrm{Km}$ between two industrial giants could be an ideal location for global climate change experiments.

Mountain economy: Most of the large rivers in the SAARC/BBIN/BIMSTEC region originate from the Himalayas and mountains. Mountains, with their tremendous sources of hydroelectricity and vital ecosystem, play significant roles in economic development, environmental protection, ecological sustainability and human wellbeing. Like "blue economy" for maritime nations, mountains of Nepal possess remarkable potential for "mountain economy" and benefit lowland nations in the region.

\section{Recommendations}

No nation can be regarded as truly independent if is not economically independent. No nation can be really sovereign if it is not able to solve its problems on its own. Nepal's independence and sovereignty have been challenged by the economic realities and political conditions (Acharya,2008,p.15).Economicindependence is not possible without development, which, in turn, is impossible without mobilizing internal human and natural resources. Therefore, Nepal must endeavor to be economically sound and politically stable if we are really going to take maximum advantages from our unique geostrategic position.

Nepal's global image has been enhanced with the participation in BRI and the US appeal into its IPS. Nepal needs its engagement 
with the US without harming the interests of immediate neighbors. Our geo-strategic position demands that Nepal cannot be a part of any strategic alliance / bloc which ultimately destabilizes equi-proximity relations with immediate neighbors (Giri, 11 Sept 2019) and cordial relations with other nations.

Our foreign policy starts with China, India and the neighborhood but it continues further. "Active involvement in the United Nations and its instruments, multilateralism, nonalignment and equi-proximity relations with immediate neighbors" are the fundamental aspects of Nepal's foreign policy (Baral, 29 June 2018, pp. 37-38). We must develop this nation with the goodwill, support and cooperation of neighbors and established powers.

Nepal must put an end to the diplomatic card play of using one neighbor against the other. We must have balanced diplomacy with both neighbors, a strategy severely constrained by a weak Ministry of Foreign External Affairs. This is further aggravated with the appointment of party indoctrinated diplomatic cadres with no or limited diplomatic exposer.

Nepal must make strategic maneuver to bring giant economies into its confidence by demonstrating diplomatic agility. Nepal has never believed in alliance and bloc politics and it should not. We should maintain our neutrality, compliant, trustworthy and bigness values (Acharya, 2018). Sino-Indian competition in diplomacy, economy, trade and connectivity here shows the bigness of Nepal.

BRI is gaining wider acceptance in Nepal and the region in spite of India's anxiety and its non-membership. China along with India wants Nepal into the 'Two plus
One'partnership. However, Prime Minister KP Sharma Oli has made clear on Nepal's stand on equal partnership of 'Three' instead of 'Two plus One concept'. The future of the Sino-Nepal relation will depend on Nepal's foreign policy skills and the nature of SinoIndian relations. Neither can we move too far from India nor should we irritate China. Nepal must assure India that its engagement with China is purely on the dimension of economics and development. If India wants to keep goodwill and influence in Nepal, we have to take advantage of the socio-cultural and religious similarities between two countries.

Nepal is an important partner in the BRI. Feasibility study for the construction Kerung -Kathmandu railway (US \$3 - 3.5 billion in 9 years) is on the process. There is a growing anxiety in Nepal on the possibility of being victim of debt-trap. Debt trap is real, but could be minimized by aligning infrastructure development along BRI plans and proactive diplomacy. We must compare the consequences of over-dependency on one neighbor with likely dividends from our north-south land connectivity potential.

Since the US led IPS being the alliance comprising of quad and other militaries of the greater Indo-Pacific region, Nepal has diplomatically rejected to be its party just because it violates our non-aligned foreign policy. Similarly, the US government's Millennium Challenge Corporation (MCC) compact is offering US $\$ 500$ million in grants to Nepal for building electricity transmission lines and roads. We should not forget the US assistance in the field of our development, security and democracy since the establishment of Nepal-US diplomatic relations on 25 April 1947. The US being a P5 member and largest fund provider 
(contributes $22 \%$ of the United Nations general budget and $28 \%$ of the peacekeeping budget), can help Nepal in various platforms of the United Nations as well. The MCC compact being solely a development package (not like the quad arrangement), it will not be wise to lose MCC grant by US. If Nepal rejects MCC support now, our diplomacy with the US as well as international credibility will be damaged. The donors will doubt the ability of government and the leaders before providing any kind of assistance to Nepal. By carefully evaluating the opportunities and threats, we should accept MCC grants by ensuring that it respects our sovereign status and does not violate our non-alignedforeign policy goals. On the other hand for the sake of development and security, neither we should be the member of any military alliance nor allow any foreign military presence/bases in our territory.

Sino-Indian trade and commerce is relying on time-consuming sea transportation Networks. Having unfeasible Nathu La Pass due to high altitude ruggedness and unresolved Sino-Indian territorial disputes, land connectivity via Nepal would economize their transportations and turn Nepal from a "land-locked to land-linked status".

Nepal's dream of becoming a transit/linked state cannot be significantly affected by the Sino-Indian political differences. It will open South Asia door to China and support India to expand their reach to TAR and CAR by significantly reducing transportation costs. To achieve this goal, we should coordinate to bring giant neighbors together to forge trilateral cooperation in a mutually constructive manner (Adhikari, Chaulagain, Dahal \& Subedi, 2070, p. 48).
Spearheaded by China and India, Asia is emerging as the dominant global economy in the twenty-first Century. Land connectivity between these countries is central to the development of intra-Asian trade networks. There is also a possibility of inter-regional trade and commerce between SAR, ASEAN and CAR. The India-Nepal-China corridor becomes an integral part of this larger strategic space.

The geopolitical risks for Nepal due to its geo-strategic position are high. In the New World Order, it is extremely difficult for small states to remain distant, non-committal, nonaligned or neutral to the gravitational pull of powerful states. Therefore, we must soon transform our dynamic geo-strategic position into asoft power asset and avoid possibilities of being the victim of great power politics by means of smart diplomacy and cooperative partnership in regional as well as global affairs.

India has realized not to interfere to its smaller neighbors. Nepal has also learnt the danger of depending too much on one neighbor. China has become a reality in SAR. It would be a great mistake if we ignore this reality.

Our abundant natural resources have drawn immense strategic relevance to our neighbors demanding collective efforts for its utilization. Therefore, economic diplomacy must go together with political and security diplomacy for our prosperity.

We must exploit tourism and huge hydroelectric potential gifted by our unique geo-strategic position. It will contribute to the transit aspiration of Nepal.

BBIN and BIMSTEC are not the substitutes of the SAARC. Nepal must put effort to make the SAARC more effective. Nepal also being 
the dialogue partner (Baral, 14 June 2019) bordering with founding member (China) of Shanghai Cooperation Organization (SCO), joining the SCO will further enhance our strategic importance beyond the region. Again, we should be careful not to be the victim of any military alliance.

\section{Conclusion}

Nepal's unique geo-strategic position as its soft power asset has become strategically important due to the rise of China and India with their global power ambitions. By active participation in the United Nations and its instruments, maintaining equi-proximity relations with immediate neighbors and cordial relations with established powers, we must exploit our bigness values presented by our geo-strategic position in the regional as well as in the global affairs.

Our geo-strategic position has offered greater possibilities of closer China-Nepal-India cooperation by means of trans-Himalayan Multi-Dimensional Connectivity potential. This would not only benefit to these nations but also enhance inter / intra-regional trade and commerce. We are no more land-locked country now rather; we are a vibrant bridge between two emerging economies. We must endeavor to take maximum advantages from our geo-strategic position by means of political consensus, stability, economic development, good governance and smart diplomacy.

\section{References}

Acharya, G.P. (2018). The bigness of smallness published in Nepal Niti. Available at https://www.nepalniti.com/2019/04/17843/.

Acharya, J. (2008). Nepal's foreign policy: A geopolitical reflection. Available at http://www.iids.org.np/sites/default/files/doc events/Dr.\%20Jayaraj\%20Acharya_Nepal $\% 27 \mathrm{~s} \% 20$ Foreign\%20Policy\%20A\%20Reflection.pdf.

Adhikari, R. \& Chaulagain, Y. P. \& Dhakal, T. P. \& Subedi, S. B. (2070). From buffer towards a bridge, Nepal's new foreign policy agenda. Kathmandu: IFA.

Baral, B. (29 June, 2018). Journal of Political Science, Volume XVIII.

Baral, B. (14 June, 2019). Shanghai Cooperation Organization and Nepal published in The Annapurna Express. Available at available at https://theannapurnaexpress.com/news/scoand-nepal-part-ii-1628.

Bhardwaj, N. (23 Jan, 2020). BRI and IndoPacific Strategy published in The Rising Nepal. Available athttp://therisingnepal.org. np/news/31219.

Couto, C. A. (1988). Elementos de Estratégia. Vol I. Instituto Altos EstudosMilitares, Lisbon.

Dahal, G. (2018). Foreign relation of Nepal with China and India. Journal of Political Science, Volume XVIII, 2018. Available at file:///C:/Users/User/Downloads/20439Article\%20Text-64786-1-10-20180626\%20 (2).pdf.

Dorji, P. (17 October 2019). Political geography of India-Nepal-China ties in Nepali Times. Available at https://www.nepalitimes. com/latest/political-geography-of-indianepal-china-ties/.

Garafano, J. (05-09 July 2004). Alternate security strategies: The strategic feasibility of various notions of security" (PDF). International Peace Research Foundation. 
Giri, A. (11 Sept 2019). Nepal disapproves of Washington's Indo-Pacific strategy, Beijing says published in Kathmandu Post. Available at https://kathmandupost. com/national/2019/09/11/nepal-disapprovesof-indo-pacific-strategy-china-s-foreignministry-says.

Gopalan, R. (17 Oct 2019). Xi's visit exposes the limits of China-Nepal strategic convergence published in The Diplomat. Available at https://thediplomat.com/2019/10/xis-visitexposes-the-limits-of-china-nepal-strategicconvergence/.

Gray, C. S. \& Sloan, G. (1999). Geopolitics, geography and strategy. London, Portland, Oregon: Frank Cass.

Kavita, K. K. (2016). The changing paradigm of India- Nepal relations: Problems and prospects. Sree Kerala Varma College, Thrissur, Kerala: PG \& Research Department of Political Science, Volume 4. Available at http://www.questjournals. org/jrbm/papers/vol4-issue5/B451015.pdf. Website: www.questjournals.org.

Kumar, R. (2017). Geo-strategic status of Nepal betweenIndiaandChina:Asecurityperspective. Gandhinagar, Gujarat: Centre for International Politics, School of International Studies, Central University of Gujarat. Available at http://www.isca.in/IJSS/Archive/v6/i11/4. ISCA-IRJSS-2017-100.pdf. Available online at: www.isca.in, www.isca.me.
Mitra, A. \& Roy, A. (2005). An overview of India-China trade and investments in C.V. Ranganathan ed. Panchasheel and the Future: perspectives on India China relations. New Delhi: Institute of Chinese Studies, Centre for the Study of Developing Societies.

Nepal, V. N. (2006). Golden bridge between India and China. Kathmandu: Telegraphnepal weekly. Available at https://ifa.org.np/wpcontent/uploads/2014/01/From-a-Buffer-forMail.pdf.

Shah, D. N. (18 Dec 2019).The Kantipur Daily.

Sigdel, A. (03 Oct 2018). China's growing footprint in Nepal: Challenges and opportunities for India. Washington, D. C.: Observer Research Forum. Available at https://www.orfonline. org/research/chinas-growing-footprint-innepal-challenges-and-opportunities-for-india/.

Singh, S. M. (23 April 2019). Belt and road initiative: Nepal's concern and commitment, published in The Himalayan Times. Available athttps://thehimalayantimes. com/opinion/belt-and-road-initiative-nepalsconcern-and-commitment/.

Sinha, A. C. (2005). Trading in uncertainty. Kathmandu: Institute of Foreign Affairs (IFA)

Spykeman, N. J. (1944). The geography of the peace. New York: Harcourt Brace.

Stone, R. (21 Oct 2019). China's silent foray in Nepal published in TRT World. Available at https://www.trtworld.com/opinion/china-ssilent-foray-into-nepal-30727. 